\title{
Antimycobacterial activity of selected medicinal plants extracts from Cameroon
}

\author{
Valerie Flore DONKENG DONFACK ${ }^{1,2,3}$, Susana ROQUE ${ }^{2,3}$, Gabriela TRIGO ${ }^{2,3}$, \\ Patrick Valere TSOUH FOKOU ${ }^{1}$, Lauve Rachel YAMTHE TCHOKOUAHA ${ }^{1,4}$, \\ Nole TSABANG ${ }^{4}$, Paul Henri AMVAM ZOLLO ${ }^{5}$, Margarida CORREIA-NEVES ${ }^{2,3}$, \\ Fabrice FEKAM BOYOM ${ }^{1 *}$
}

\footnotetext{
${ }^{1}$ Antimicrobial Agents Unit, Laboratory for Phytobiochemistry and Medicinal Plants Studies, University of Yaoundé I, P.O. Box 812, Yaoundé, Cameroon.

${ }^{2}$ Life and Health Sciences Research Institute (ICVS), School of Health Sciences, University of Minho, 4710-057, Braga, Portugal.

${ }^{3}$ ICVS/3B's-PT Government Associate Laboratory, Braga/Guimarães, Portugal.

${ }^{4}$ Institute of Medical Research and Medicinal Plants Studies (IMPM), Yaoundé, Cameroon.

${ }^{5}$ University of Ngaoundéré, Biochemistry, Ngaoundéré, Cameroon.

*Corresponding author, E-mail: fabrice.boyom@fulbrightmail.org; Tel.: +237-7727 6585
}

\begin{abstract}
New drugs are highly needed to control mycobacterial infections. This study aimed at screening ethnobotanically selected plants extracted using organic solvents for their antimycobacterial activity. In vitro assays were performed on Mycobacterium smegmatis, Mycobacterium avium, Mycobacterium bovis Bacille Calmette Guerin (BCG), Mycobacterium tuberculosis and Mycobacterium ulcerans using the Resazurin Microtiter Assay. Cytotoxicity was assessed on Human lung fibroblast cells (MRC5) and bone marrow-derived macrophages (BMDM) using the MTS tetrazolium assay. The most promising extract from Annickia chlorantha stem bark (ACsbI) was tested for intracellular antimycobacterial activity against M. smegmatis using infected BMDM. Sixty crude extracts, 19 fractions, and 2 purified compounds were obtained from 19 Cameroonian medicinal plants. Results showed that crude extracts mainly inhibited BCG, while interface fractions from A. chlorantha stem bark (ACsbI) and stem (ACstI) displayed the strongest activity against $M$. ulcerans, with Minimal Inhibitory Concentrations (MIC) of 1.95 and $7.81 \mu \mathrm{g} / \mathrm{ml}$ respectively. Two compounds purified from Sorindeia juglandifolia fruits (SJfr 3.6 and SJfr 4.5) showed activity against BCG and $M$. ulcerans at $3.9 \mu \mathrm{g} / \mathrm{ml}$ and $62.5 \mu \mathrm{g} / \mathrm{ml}$ respectively. Finally, ACsbI showed no toxicity against MRC5 cells and BMDM and inhibited the growth of intracellular M. smegmatis. The results achieved in this investigation support the traditional to use of these plants and the need to investigate them in deeper details to be able to find alternatives for the existing antimycobacterial drugs.
\end{abstract}

(C) 2014 International Formulae Group. All rights reserved.

Keywords: Mycobacterium, tuberculosis, Buruli ulcer, antimycobacterial activity, cytotoxicity, Annickia chlorantha, ethnobotanical survey.

\section{INTRODUCTION}

Mycobacteria constitute a very heterogeneous genus, comprising highly pathogenic as well as opportunistic or nonpathogenic species. Amongst the pathogenic species, Mycobacterium 
tuberculosis, the causative agent of tuberculosis (TB), is the leading one, responsible for an estimated one-third of the world's human population infection (WHO, 2004; TB Alliance, 2011). Buruli ulcer (BU), caused by Mycobacterium ulcerans, is globally the third most frequent mycobacterial disease after TB and leprosy (Asiedu et al., 2000; WHO, 2011). However, in some countries, as Benin and Côte d'Ivoire, the number of cases may exceed those of TB and leprosy (Asiedu et al., 2000). On the other hand, opportunistic or nonpathogenic mycobacteria such as Mycobacterium avium and Mycobacterium smegmatis can cause disease in imunocompromised people such as AIDS patients (Daley and Griffith, 2010; Sexton and Harrison, 2008; Cangelosi et al., 2001). Infections with these species are very hard to treat, requiring multi-drug therapy for prolonged periods (WHO, 2004; TB Alliance, 2011). Furthermore, drug-resistant strains render the treatment even more difficult, highlighting the need for a drug discovery pipeline to ensure the availability of new chemical entities with improved mechanisms of antimycobacterial action.

A large proportion of the world population relies on traditional medicine for their primary healthcare, due to cultural believes or lack of alternatives (WHO 2004; Hannan et al., 2011; Anon, 2002). Within this framework, plant products have proven interesting antimicrobial potency (Okunade et al., 2004, Vikrant, 2011). In Cameroon, there is a rich tradition of using herbal medicine for the treatment of various mycobacterial infections (Adjanohoun et al., 1996; Kimbi et al., 1996; Focho et al., 2010).

This paper reports the antimycobacterial activity of 60 crude extracts, 19 fractions, and 2 purified compounds from 19 Cameroonian medicinal plants selected based on their traditional uses against infectious diseases in general and particularly TB and related diseases.

\section{MATERIALS AND METHODS \\ Collection of plant materials}

Nineteen plants were selected based on their ethnobotanical use for the treatment of various ailments including cough, bronchitis, chest complaints, pneumonia, TB and other related diseases (Nishiyama et al., 2004;
Ibekwe and Orok, 2010). The plants were subsequently collected between December 2009 and October 2010 at Mt Kalla (Yaoundé area-Centre region), Lolodorf (South region of Cameroon), and Dschang (West region). The ethnobotanical survey was conducted in strict respect of the current regulations of biodiversity protection and rural population's customary rights. In the preliminary step of the survey, legal authorities (villages' heads) from each study site were contacted to seek authorization to investigate within their communities. During a face-to-face interaction, the purpose and the procedure of the work, as well as the expected benefits and rights were explained to villages' heads. The traditional herbal practitioners willing to participate on the study (or their interpreters) had signed the informed consent form before further interactions. The data were collected following a questionnaire prepared for the study by Dr. Nole Tsabang, an ethnobotanist at the Institute for Medical Research and Medicinal Plants Study, Yaoundé, Cameroon. Voucher specimens of each plant were dried and deposited at the Cameroon National Herbarium, Yaoundé. The information on plant materials is summarized in Table 1 where plants are listed with their traditional uses, voucher specimen's reference numbers, the solvent and yields of extraction.

\section{Plant extraction}

Air-dried (at room temperature) and ground (using a blender) plant materials were extracted by maceration using appropriate solvents. Annonaceae plants samples were extracted according to the method previously described by Alali et al. (1999). This method was chosen because it is designed to isolate acetogenins (or rich fractions) that were shown to exert high potency against bacteria (Vairappan and Tan, 2009; Alali et al., 1999). Plant powders $(500 \mathrm{~g})$ were individually macerated in $95 \%$ ethanol for $72 \mathrm{~h}$. The dried ethanolic extracts obtained were further partitioned between water $\left(\mathrm{H}_{2} \mathrm{O}\right)$ and methylene chloride $\left(\mathrm{CH}_{2} \mathrm{Cl}_{2}\right)(1: 1, \mathrm{v} / \mathrm{v})$. The $\mathrm{CH}_{2} \mathrm{Cl}_{2}$ residues were partitioned between hexane and $90 \%$ methanol $(1: 1, \mathrm{v} / \mathrm{v})$. The different fractions were evaporated to dry under reduced pressure using a Büchi R111 Rotavapor. The water layers were evaporated under ventilation at room temperature. In 
addition, interface precipitates were obtained during residues partition between $\mathrm{CH}_{2} \mathrm{Cl}_{2} / \mathrm{H}_{2} \mathrm{O}$.

Samples of non Annonaceae plants that do not contain acetogenins were extracted by repeated maceration in methanol. These included Aframomum melegueta, Chlorophytum macrophyllum, Solanum aculeastrum, Spilanthes filicaulis and Sorindeia juglandifolia.

Following a Label extension strategy (Nwaka and Hudson, 2006), methanolic crude extract, fractions (SJfr 1.1, SJfr 2.1, SJfr 2.2, SJfr 2.3, SJfr 3.1, SJfr 3.2, SJfr 3.3, SJfr 3.41, SJfr 3.42, SJfr 3.5, SJfr 4.1, SJfr 4.2, SJfr 4.3, SJfr 4.4), and compounds [2,3,6-trihydroxy benzoic acid (SJfr 3.6) (formula 1) and 2,3,6trihydroxy methyl benzoate (SJfr 4.5) (formula 2)] from the fruit of $S$. juglandifolia that were previously prepared in our laboratory and that showed good potency against infectious pathogens (Kamkumo et al., 2012) were also screened for antimycobacterial activity.

\section{Evaluation of the biological activities Preparation of stock solutions}

Stock solutions $(100 \mathrm{mg} / \mathrm{ml}$ for plants crude extracts and $2 \mathrm{mg} / \mathrm{ml}$ for fractions and purified compounds) were prepared by dissolving each extract in $2 \% \mathrm{DMSO} /$ distilled water, and filtrating through a $0.22 \mu \mathrm{m}$ syringe filter. For the intracellular antimycobacterial activity and cytotoxicity assays, stock solutions were prepared using 2\% DMSO in complete Dulbecco's modified Eagle's medium [cDMEM, consisting of Dulbecco's modified Eagle's medium (DMEM) (Gibco) with $10 \mathrm{mM}$ HEPES (Gibco), $1 \mathrm{mM}$ sodium pyruvate (Gibco), 2 $\mathrm{mM}$ L-glutamine (Gibco), 10\% heatinactivated fetal bovine serum (Sigma Aldrich)], filtrated through a $0.22 \mu \mathrm{m}$ syringe filter. The stock solutions were serially diluted either in Middlebrook $7 \mathrm{H} 9$ medium supplemented with ADC (Albumin, Dextrose, Catalase) or in cDMEM for specific experiments. Positive controls were prepared at $1 \mathrm{mg} / \mathrm{ml}$ for ethambutol (EMB) and streptomycin (SM) in distilled water and sterilized through a $0.22 \mu \mathrm{m}$ syringe filter.

Bacterial strains and growth conditions

The following mycobacterial strains were used in the experiments: $M$. smegmatis strain $\mathrm{mc}^{2} 155$ from the American Type Culture Collection (ATCC 70008); M. avium strain 2447 smT (smooth-transparent) isolated from an AIDS patient and obtained from Dr. F. Portaels (Institute of Tropical Medicine, Antwerp, Belgium); M. ulcerans strain 1615 obtained from the University of Tennessee, USA; BCG Pasteur and M. tuberculosis H37 $\mathrm{Rv}$, obtained from the Trudeau Institute, USA. Mycobacteria were grown at $37{ }^{\circ} \mathrm{C}$ on solid Middlebrook 7H10 (M. smegmatis and $M$. avium) or Middlebrook 7H11 medium (BCG and M. tuberculosis) all supplemented with OADC (Oleic-Acid-Albumin-DextroseCatalase) and $0.5 \%$ glycerol. M. ulcerans was grown at $32{ }^{\circ} \mathrm{C}$ on Middlebrook $7 \mathrm{H} 9$ agar medium enriched with OADC.

To prepare the inocula, M. smegmatis, M. avium, BCG, and M. tuberculosis were freshly subcultured in Middlebrook $7 \mathrm{H} 9$ medium containing $0.05 \%$ Tween 80 and $\mathrm{ADC}$ at $37{ }^{\circ} \mathrm{C}$. M. ulcerans was subcultured on solid Middlebrook $7 \mathrm{H} 9$ medium containing OADC enrichment for 6 weeks at $32{ }^{\circ} \mathrm{C}$. The mycobacterial strains were used at their exponential growth phase, evaluated by their individual growth curve.

Inocula of bacteria used for in vitro experiments, were prepared as described by Singh et al. (2012) and Yemoa et al. (2011) with few modifications. Briefly, inocula of $M$. smegmatis, BCG, M. ulcerans, M. avium, and M. tuberculosis were prepared following the McFarland standards, and concentration of viable bacteria was obtained by enumerating colony forming unit (CFU) per $\mathrm{ml}$ on solid medium. The concentration of bacteria used in the experiments was approximately: $10^{5}$ $\mathrm{CFU} / \mathrm{ml}$ for $M$. smegmatis, BCG, and $M$. tuberculosis; $10^{6} \mathrm{CFU} / \mathrm{ml}$ for M. ulcerans, and $10^{8} \mathrm{CFU} / \mathrm{ml}$ for $M$. avium. Prior to antimycobacterial assay, the absence of contamination was confirmed by culturing in the Brain and Heart Infusion (BHI) medium agar and using Ziehl-Neelsen staining.

Assessment of in vitro antimycobacterial activity of plant extracts

The antimycobacterial activity was assessed in 96 wells microtiter plates (Corning, Spain) using the Resazurin Microtiter Assay (REMA) as described by Singh et al. (2012). Fixed concentration of $12.5 \mathrm{mg} / \mathrm{ml}$ for 60 crude extracts, $0.25 \mathrm{mg}$ $/ \mathrm{ml}$ for 19 fractions and 2 compounds were 
added to wells containing $100 \mu \mathrm{l}$ of bacterial inocula and incubated at $37{ }^{\circ} \mathrm{C}$ for 1 day for M. smegmatis, 5 days for $M$. avium and BCG, and 7 days for M. tuberculosis. M. ulcerans was incubated for 15 days at $32{ }^{\circ} \mathrm{C}$. Positive controls consisted of EMB at $1.875 \mu \mathrm{g} / \mathrm{ml}$, $0.166 \mathrm{mg} / \mathrm{ml}$ and $3 \mu \mathrm{g} / \mathrm{ml}$ for $M$. smegmatis, M. avium and BCG, respectively, and of SM at $2 \mu \mathrm{g} / \mathrm{ml}, 18 \mu \mathrm{g} / \mathrm{ml}$ and $4 \mu \mathrm{g} / \mathrm{ml}$ respectively for $M$. ulcerans, $M$. avium and $M$. tuberculosis. Negative control wells contained no drugs and blank contained no inoculum and/or drug. Upon incubation periods, $30 \mu \mathrm{l}$ of $0.01 \%$ resazurin (Acros Organic NV) were added to individual wells and the plates reincubated for additional 1 to 3 days and checked daily for color change. Change in resazurin color from blue to pink indicated reduction of the indicator and thus bacterial growth.

The Minimal Inhibitory Concentrations (MIC) of inhibitors was assessed using the same approach. Briefly, twofold serially diluted selected extracts were incubated in the range of $12,500-97 \mu \mathrm{g} / \mathrm{ml}$ for crude extracts and $250-1.95 \mu \mathrm{g} / \mathrm{ml}$ for fractions and purified compounds with inocula in 96 wells microtiter plate (Corning, Spain). EMB and SM were used as positive controls. The MIC was defined as the lowest drug concentration that prevented visible growth of bacteria displayed by no color change.

Minimal Bactericidal Concentrations (MBC) of promising plant extracts was assessed by sub-culturing MIC test plates on solid nutrient Middlebrook 7H9, 7H10, and 7H11. The MBC was considered as the minimal concentration of plant extract needed to kill most $(\geq 99.9 \%)$ of the initial inoculum after incubation for a fixed length of time under a given set of conditions (NCCLS, 1999). All the experiments were done in duplicate and repeated 3 times. Fractions exhibiting antimycobacterial activity with MIC $\leq 7.81 \mu \mathrm{g} / \mathrm{ml}$ against at least 1 mycobacterial species (ACstI, ACsbI, and SJfr 3.6) were selected and assessed for cytotoxicity against MRC5 cells.

Assessment of the cytotoxicity of promising plants extracts and fractions

Plant extracts showing antimycobacterial activity were assessed for cell cytotoxicity against MRC5 cells. Subsequently, the cytotoxicity profile of 1 fraction (ACsbI) that showed no toxic effects on MRC5 cells was assessed on BMDM prepared from mice (C57BL/6 Ly5.1) as described by Oliveira et al. (2005). The cytotoxic effect of selected plant extracts was evaluated by MTS assay ([3-(4,5dimethylthiazol-2-yl)-5-(3-carboxymethoxyphenyl)-2-(4-sulfophenyl)-2H-tetrazolium] (Promega, USA) after $48 \mathrm{~h}$ of incubation. Detection of cell viability was based on the reduction of the tetrazolium salt MTS to water-soluble formazan dye by metabolically active cells. Briefly, $100 \mu 1$ of MRC5 cells or BMDM were cultured in 96-well plates at $1 \times$ $10^{5}$ cells $/ \mathrm{ml}, 24 \mathrm{~h}$ before adding $100 \mu \mathrm{l}$ of extract at $0,125,250$, and $500 \mu \mathrm{g} / \mathrm{ml}$ final concentration and incubated for $48 \mathrm{~h}$ at $37{ }^{\circ} \mathrm{C}$ in a $5 \% \mathrm{CO}_{2}$ humidified atmosphere. Upon the incubation period, the medium was replaced with the same volume of cDMEM. MTS reagent was added to each well and incubated for $2 \mathrm{~h}$ at $37{ }^{\circ} \mathrm{C}$. Untreated cells were used as negative control. The absorbance was recorded at $490 \mathrm{~nm}$ using an ELISA plate reader (BioteK EL800, USA). The readout was directly proportional to the number of viable cells in culture (Promega, 2011). Percent inhibition of MRC5 cells was calculated using optical density. The value of cell cytotoxicity at $50 \%\left(\mathrm{IC}_{50}\right)$ in the MTS assay was defined as the concentration of test extract resulting in a 50\% reduction of absorbance compared with untreated cells and obtained using Graph Pad Prism 5.0.

\section{Assessment of the intracellular antimycobacterial activity of A. chlorantha stemback ACsbI fraction}

To assess the intracellular activity of ACsbI that exerted no significant cytotoxicity on BMDM and MRC5 cells, BMDM were cultured in 96-well plates at $1 \times 10^{5}$ cells $/ \mathrm{ml}$ for $24 \mathrm{~h}$ and the culture medium replaced with $100 \mu \mathrm{l}$ of $M$. smegmatis inoculum containing $5 \times 10^{5} \mathrm{CFU}$. Upon a $4 \mathrm{~h}$ phagocytosis period at $37{ }^{\circ} \mathrm{C}$ under $5 \% \mathrm{CO}_{2}$ (Rastogi et al., 1987), free bacteria were washed out and $100 \mu 1$ of ACsbI at MIC value $(250 \mu \mathrm{g} / \mathrm{ml}$ in cDMEM, $20 \%$ LCCM, 2\% DMSO) added and incubated at $37{ }^{\circ} \mathrm{C}$ under $5 \% \quad \mathrm{CO}_{2}$ for 24 and $48 \mathrm{~h}$ (Rastogi et al., 1987 ; Sharbati-Tehrani et al., 2005). The infected BMDM were lysed adding $5 \mu \mathrm{l}$ of saponin $(10 \%)$, diluted and plated on the Middlebrook 7H10 medium for 3 days at $37{ }^{\circ} \mathrm{C}$, and the $\mathrm{CFU}$ thereafter 
enumerated. The experiment was done in triplicate and the results expressed as $\log _{10}$ CFU.

\section{Statistical analysis}

Results are expressed as Means \pm SD. The comparison between control and treated samples was assessed by one-way ANOVA. The intracellular activity was evaluated by two-way ANOVA using the GraphPad Prism 5.0 software. Statistically significant differences were considered for $\mathrm{P}$ values < 0.05 .

\section{RESULTS}

The 19 plants resulting from the ethnobotanical survey are listed in Table 1, with indication of their traditional uses, plant parts studied, extracts, fraction and yields obtained (60 crude extracts, 19 fractions, and 2 purified compounds were obtained with yields ranging from 0.019 to $25.44 \%$ ) calculated in percentage $(\mathrm{w} / \mathrm{w})$ relative to the starting plant material.

The extracts were initially screened against $M$. smegmatis, $M$ avium, BCG, $M$. ulcerans, and $M$. tuberculosis at unique concentrations of $12,500 \mu \mathrm{g} / \mathrm{ml}$ for crude extracts and $250 \mu \mathrm{g} / \mathrm{ml}$ for fractions and compounds. From the results obtained, 22 extracts and fractions and 2 purified compounds (Table 2) deriving from 10 plants species (Aframomum melegueta, Spilanthes filicaulis, Chlorophytum macrophyllum, Polyalthia Suaveolens, Sorindeia juglandifolia, Annickia chlorantha, Anonidium mannii, Uvaria baumannii, Xylopia africana and Polyalthia oliveri) exhibited inhibitory actions, and were therefore selected for the MIC and MBC determination.

From the assessment of the selected extracts, MIC and MBC were determined as presented in Table 2. Crude extracts mainly acted on $\mathrm{BCG}$, the most potent being UBtwMeOH $(\mathrm{MIC}=1,562 \mu \mathrm{g} / \mathrm{ml} ; \mathrm{MBC}=$ $3,125 \mu \mathrm{g} / \mathrm{ml}), \mathrm{XArH}_{2} \mathrm{O}(\mathrm{MIC}=3,125 \mu \mathrm{g} / \mathrm{ml}$; $\mathrm{MBC}=3,125 \mu \mathrm{g} / \mathrm{ml}) ; \mathrm{CMr} \quad(\mathrm{MIC}=3,125$ $\mu \mathrm{g} / \mathrm{ml} ; \quad \mathrm{MBC}=6,250 \mu \mathrm{g} / \mathrm{ml}), \quad$ and AMntwMeOH $(\mathrm{MIC}=3,125 \mu \mathrm{g} / \mathrm{ml} ; \mathrm{MBC}=$ $6,250 \mu \mathrm{g} / \mathrm{ml})$. The remaining extracts presented MIC/MBC values equal or superior to $6,250 \mu \mathrm{g} / \mathrm{ml}$. PSsbMeOH and $\mathrm{XArH}_{2} \mathrm{O}$ showed the broadest range of action. On the other hand, $M$. ulcerans appeared to be highly susceptible to the methanolic crude extract of P. suaveolens (PSsbMeOH), with $\mathrm{MIC}$ and MBC values equal to $3,125 \mu \mathrm{g} / \mathrm{ml}$.

Concerning the susceptibility of mycobacteria to fractions, A. chlorantha stem bark and stem interfaces displayed the strongest activity against $M$. ulcerans, with low MIC and MBC values at 1.95 and 62.5 $\mu \mathrm{g} / \mathrm{ml}$ respectively for $\mathrm{ACsbI}$, and 7.81 and $7.81 \mu \mathrm{g} / \mathrm{ml}$ for ACstI. The other promising fractions acted at concentrations equal or higher than $31.25 \mu \mathrm{g} / \mathrm{ml}$, and mainly against BCG.

The 2 compounds purified from the fruits of $S$. juglandifolia (SJfr 3.6 = 2,3,6trihydroxy benzoic acid and SJfr 4.5= 2,3,6trihydroxy methyl benzoate) showed antimycobacterial activity against BCG and M. ulcerans with respective MIC values of 3.9 $\mu \mathrm{g} / \mathrm{ml}$ and $62.5 \mu \mathrm{g} / \mathrm{ml}$.

From the MTS cytotoxicity assays using MRC5 cells, ACsbI proved to be safe at the highest concentration tested $\left(\mathrm{IC}_{50}>500\right.$ $\mu \mathrm{g} / \mathrm{ml})$. The 2 other fractions, ACstI and SJfr 3.6, showed cytotoxicity against MRC5 (Table 3) with $\mathrm{IC}_{50}$ values of $50.82 \mu \mathrm{g} / \mathrm{ml}$ and $139.4 \mu \mathrm{g} / \mathrm{ml}$ respectively.

As shown in Table 3, only 1 extract from A. chlorantha (ACsbI) was found to be safe at 2 fold the MIC value (activity against M. smegmatis) and was therefore assessed against BMDM. ACsbI was also tested for cytotoxicity against BMDM (Figure 1) and showed no cytotoxic effects at MIC value and was considered for intracellular activity assessment.

For the intracellular antimycobacterial activity, BMDM infected with $M$. smegmatis were treated with the extract (ACsbI) and the result evaluated after 0,24 and $48 \mathrm{~h}$ postinfection as showed in Figure 2.

As shown in Figure 2, the bacterial load in untreated macrophages nearly doubled within $48 \mathrm{~h}$, while it slightly decreased or remained constant for BMDM treated with ACsbI. The time-kill kinetic showed that the activity of ACsbI is almost constant throughout the $48 \mathrm{~h}$ of exposition. This result suggests that drugs inhibited the intracellular mycobacterial growth. 
<smiles>O=C(O)c1c(O)ccc(O)c1O</smiles>

(1) SJfr 3.6: 2,3,6-trihydroxybenzoic acid Yield: $0.062 \% ; \mathrm{m} / \mathrm{z}=170 ; \mathrm{mp}=188.5-190$; yellow crystals<smiles>COC(=O)c1c(O)ccc(O)c1O</smiles>

(2) SJfr 4.5: 2,3,6-trihydroxymethyl benzoate. Yield: $0.0017 \% ; \mathrm{m} / \mathrm{z}=184 ; \mathrm{mp}=139-140.5$; pale yellow crystals

The synthesis of these compounds was previously described by Kreuchunas and Mosher (1956).

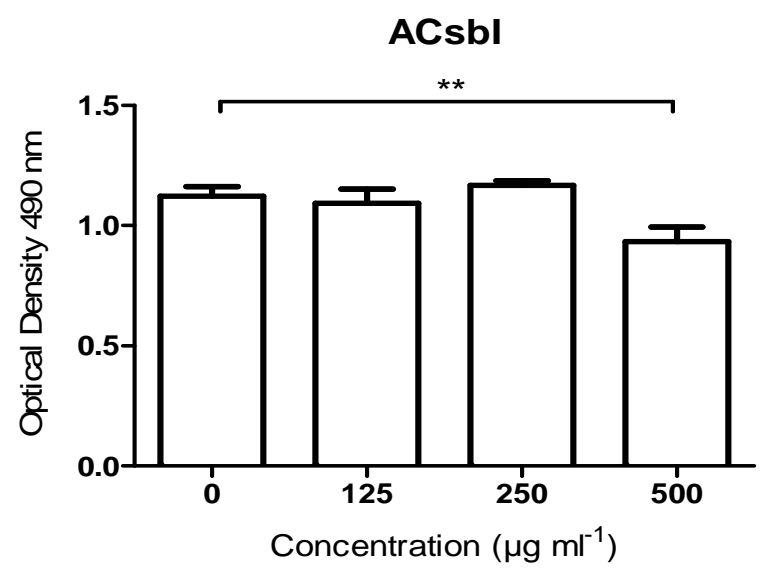

Figure 1: Cytotoxicity of Annickia chlorantha (ACsbI) against BMDM. The toxicity was assessed using the MTS assay. The cells were treated for $48 \mathrm{~h}$ with different drug concentrations. OD was measured at $490 \mathrm{~nm}$. Data are reported as means \pm standard deviation. Significant differences were calculated by comparing results in the presence of cells treated or not with ACSbI at different concentrations. Calculations were performed using one way ANOVA [F (3, $8)=13.79 ; * *, p=0.0016]$.

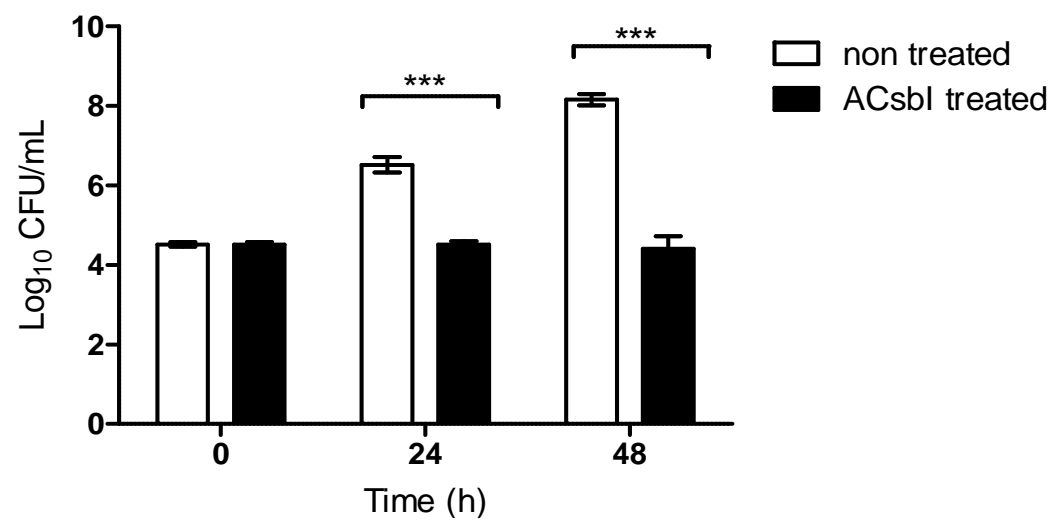

Figure 2: Intracellular antimycobacterial effect of $A$. chloranta stem bark extract (ACsbI) against M. smegmatis infecting BMDM. Number of intracellular surviving bacteria at 0,24 and $48 \mathrm{~h}$ in untreated and treated BMDM inoculated with $5 \times 10^{5} \mathrm{CFU}$ was determined. Data are reported as means \pm standard deviation. Significant differences were calculated by comparing treated and untreated cell at different time intervals. $0 \mathrm{~h}$ post-infection refers to $4 \mathrm{~h}$ after phagocytosis of M. smegmatis. Calculations were performed using two-way ANOVA. F $(1,12)=569.7$; ***, $\mathrm{p}<.001$. 
Table 1: List of plant species with their traditional uses and extraction yields.

\begin{tabular}{|c|c|c|c|c|c|c|c|c|}
\hline Plant family & Species & $\begin{array}{l}\text { Voucher } \\
\text { specimen } \\
\text { number }\end{array}$ & Traditional uses & References & $\begin{array}{c}\text { Parts } \\
\text { used }\end{array}$ & $\begin{array}{l}\text { *Solvent of } \\
\text { extraction }\end{array}$ & Extracts code & $\begin{array}{c}* * \text { Yield } \\
(\%)\end{array}$ \\
\hline \multirow[b]{4}{*}{ Zingiberaceae } & \multirow[b]{4}{*}{$\begin{array}{l}\text { Aframomum } \\
\text { melegueta } \mathrm{K} . \\
\text { SChum. }\end{array}$} & \multirow[b]{4}{*}{ 43123/HNC } & \multirow{4}{*}{$\begin{array}{l}\text { Dysmenorrhea, bronco- } \\
\text { pulmonary disorders, sexual } \\
\text { asthenia, female sterility, hay } \\
\text { fever, migraines and wound } \\
\text { purgative, } \\
\text { Galactogogue, anthelmintic } \\
\text { and haemostatic agent } \\
\text { Diarrhea, smallpox, } \\
\text { chickenpox, wounds, cough, } \\
\text { anaemia, rheumatism, } \\
\text { measles, malaria, toothache, } \\
\text { cardiovascular diseases, } \\
\text { diabetics and fertility control. } \\
\text { Tuberculosis. Buruli ulcer }\end{array}$} & \multirow{4}{*}{$\begin{array}{l}\text { (Tane et al., 2006; } \\
\text { Adeleye et al., } \\
\text { 2008; Kadiri, } \\
\text { 2009; Ibekwe and } \\
\text { Orok, 2010; } \\
\text { Yemoa et al., } \\
\text { 2011) }\end{array}$} & Leaf & Methanol & AMl & 5.40 \\
\hline & & & & & Fruit & Methanol & AMfr & 6.78 \\
\hline & & & & & Root & Methanol & $\mathrm{AMr}$ & 3.78 \\
\hline & & & & & Stem & Methanol & AMst & 2.55 \\
\hline \multirow{5}{*}{ Annonaceae } & \multirow{5}{*}{$\begin{array}{l}\text { Annickia chloranta } \\
\text { (Oliv.) Setten and } \\
\text { Maas }\end{array}$} & \multirow{5}{*}{ 32065/SRF/Cam } & \multirow{5}{*}{$\begin{array}{l}\text { Jaundice and urinary tract } \\
\text { infections, } \\
\text { stomach malaria, } \\
\text { tuberculosis, hepatitis and } \\
\text { some forms of ulcer, Sore, } \\
\text { fevers, vomiting, fatigue, } \\
\text { Rheumatism treatment }\end{array}$} & \multirow{5}{*}{$\begin{array}{l}\text { (Adjanohoun et } \\
\text { al., 1996; Kimbi } \\
\text { et al., 1996; } \\
\text { Boyom } \\
\text { et al., 2009; Bele } \\
\text { et al., 2011; } \\
\text { Tsabang et al., } \\
\text { 2012) }\end{array}$} & \multirow{3}{*}{$\begin{array}{l}\text { Stem } \\
\text { bark }\end{array}$} & Ethanol & $\mathrm{ACsbMeOH}$ & 2.90 \\
\hline & & & & & & Ethanol & ACsbI & 1.98 \\
\hline & & & & & & Ethanol & $\mathrm{ACsbH}_{2} \mathrm{O}$ & 0.31 \\
\hline & & & & & \multirow[t]{2}{*}{ Stem } & Ethanol & ACstMeOH & 4.60 \\
\hline & & & & & & Ethanol & ACstI & 0.98 \\
\hline \multirow[t]{4}{*}{ Annonaceae } & \multirow{4}{*}{$\begin{array}{l}\text { Anonidium mannii } \\
\text { Gaertm (D. Oliver) } \\
\text { Engl.and Diels }\end{array}$} & \multirow[t]{4}{*}{$45582 \mathrm{HNC}$} & \multirow{4}{*}{$\begin{array}{l}\text { Male infertility, complication } \\
\text { of pregnancy and childbirth, } \\
\text { treatment of abscess }\end{array}$} & \multirow[t]{4}{*}{$\begin{array}{l}\text { (Noumi et al., } \\
\text { 2011) }\end{array}$} & $\begin{array}{l}\text { Stem } \\
\text { bark }\end{array}$ & Ethanol & AMnsbMeOH & 0.31 \\
\hline & & & & & Twig & Ethanol & AMntwMeOH & 0.30 \\
\hline & & & & & Leaf & Ethanol & AMnlMeOH & 1.65 \\
\hline & & & & & Leaf & Ethanol & AMnlI & 2.87 \\
\hline
\end{tabular}


V. F. DONKENG DONFACK et al. / Int. J. Biol. Chem. Sci. 8(1): 273-288, 2014

\begin{tabular}{|c|c|c|c|c|c|c|c|c|}
\hline & & & & & Twig & Ethanol & $\begin{array}{l}\text { AMntw } \\
\mathrm{CH}_{2} \mathrm{CL}_{2}\end{array}$ & 0.55 \\
\hline \multirow[t]{7}{*}{ Annonaceae } & \multirow{7}{*}{$\begin{array}{l}\text { Annona muricata } \\
\text { Linn }\end{array}$} & \multirow[t]{7}{*}{ 32879/ HNC } & \multirow{7}{*}{$\begin{array}{l}\text { Boil, cough, diarrhea, } \\
\text { dermatosis, hypertension, } \\
\text { rheumatism and styptic, } \\
\text { worms and parasites. } \\
\text { headache, fever, toothache, } \\
\text { asthma. }\end{array}$} & \multirow{7}{*}{$\begin{array}{l}\text { (Mat Salleh and } \\
\text { Ahmad, 1989; } \\
\text { Adewole et al., } \\
\text { 2009; Chan and } \\
\text { Roslida , 2012) }\end{array}$} & Leaf & Ethanol & AnMlMeOH & 4.85 \\
\hline & & & & & $\begin{array}{l}\text { Fruit } \\
\text { pulp }\end{array}$ & Ethanol & AnMppMeOH & 2.32 \\
\hline & & & & & Seed & Ethanol & AnMsMeOH & 3.49 \\
\hline & & & & & Root & Ethanol & AnMrMeOH & 1.43 \\
\hline & & & & & Pericarp & Ethanol & AnMPMeOH & 0.98 \\
\hline & & & & & Leaf & Ethanol & AnMlI & 1.04 \\
\hline & & & & & Twig & Ethanol & AnMtwMeOH & 1.77 \\
\hline \multirow[t]{3}{*}{ Annonaceae } & \multirow{3}{*}{$\begin{array}{l}\text { Chlorophytum } \\
\text { macrophyllum (A. } \\
\text { Rich.) Asch. }\end{array}$} & \multirow[t]{3}{*}{$373445 / \mathrm{HNC}$} & \multirow{3}{*}{$\begin{array}{l}\text { Cough or cough with } \\
\text { haemoptysis. }\end{array}$} & \multirow{3}{*}{$\begin{array}{l}\text { (Adjanohoun et } \\
\text { al., 1996) }\end{array}$} & Root & Methanol & $\mathrm{CMr}$ & 12.18 \\
\hline & & & & & Stem & Methanol & CMst & 10.12 \\
\hline & & & & & Leaf & Methanol & CMl & 2.50 \\
\hline \multirow[t]{3}{*}{ Annonaceae } & \multirow{3}{*}{$\begin{array}{l}\text { Monodora } \\
\text { myristica (Gaertn.) } \\
\text { Dunal }\end{array}$} & \multirow[t]{3}{*}{ 27690/SFR/CAM } & \multirow{3}{*}{$\begin{array}{l}\text { Buruli ulcer, dysentery, } \\
\text { diabetes, bacterial infections, } \\
\text { fevers, pain and snake bites, } \\
\text { hemorrhoids, stomachache, } \\
\text { and febrile pains }\end{array}$} & \multirow{3}{*}{$\begin{array}{l}\text { (Yemoa et al., } \\
\text { 2011; Bele et al., } \\
\text { 2011; Igoli et al., } \\
\text { 2011) }\end{array}$} & $\begin{array}{l}\text { Stem } \\
\text { bark }\end{array}$ & Ethanol & MMsbMeOH & 0.56 \\
\hline & & & & & Twig & Ethanol & MMtwMeOH & 0.27 \\
\hline & & & & & Leaf & Ethanol & $\mathrm{MMlMeOH}$ & 0.65 \\
\hline Annonaceae & $\begin{array}{l}\text { Piptostigma } \\
\text { calophylium } \\
\text { Mildbr. and Diels }\end{array}$ & $38333 \mathrm{HNC}$ & Urinary tract infections & Local claims & Leaf & Ethanol & $\mathrm{PClMeOH}$ & 1.64 \\
\hline \multirow[t]{3}{*}{ Annonaceae } & \multirow[t]{3}{*}{$\begin{array}{l}\text { Polyalthia oliveri } \\
\text { Engl. and Diels }\end{array}$} & \multirow[t]{3}{*}{ 19416SRF/Cam } & \multirow[t]{3}{*}{ Malaria } & \multirow[t]{3}{*}{$\begin{array}{l}\text { (Boyom et al., } \\
\text { 2009) }\end{array}$} & $\begin{array}{l}\text { Stem } \\
\text { bark }\end{array}$ & Ethanol & POsbMeOH & 1.04 \\
\hline & & & & & Twig & Ethanol & POtwMeOH & 0.64 \\
\hline & & & & & Twig & Ethanol & POtwI & 0.37 \\
\hline \multirow[t]{2}{*}{ Annonaceae } & \multirow{2}{*}{$\begin{array}{l}\text { Polyalthia } \\
\text { suaveolens Engl. } \\
\text { and Diels }\end{array}$} & \multirow[t]{2}{*}{ 1227/SRF/CAM } & \multirow[t]{2}{*}{ Malaria } & \multirow[t]{2}{*}{$\begin{array}{l}\text { (Tsabang et al., } \\
\text { 2012) }\end{array}$} & $\begin{array}{l}\text { Stem } \\
\text { bark }\end{array}$ & Ethanol & PSsbMeOH & 2.04 \\
\hline & & & & & Leaf & Ethanol & PSIMeOH & 7.86 \\
\hline Solanaceae & Solanum & 23965SRFCam & Cough and pneumonia & (Adjanohoun et & Leaf & Methanol & SAl & 25.44 \\
\hline
\end{tabular}


V. F. DONKENG DONFACK et al. / Int. J. Biol. Chem. Sci. 8(1): 273-288, 2014

\begin{tabular}{|c|c|c|c|c|c|c|c|c|}
\hline & \multirow[t]{2}{*}{ aculeastrum Dunal } & & & \multirow[t]{2}{*}{ al., 1996) } & Stem & Methanol & SAst & 2.80 \\
\hline & & & & & Fruit & Methanol & SAfr & 10.57 \\
\hline \multirow[t]{17}{*}{ Anacardiaceae } & \multirow{17}{*}{$\begin{array}{l}\text { Sorindeia } \\
\text { juglandifolia A. } \\
\text { Rich. }\end{array}$} & \multirow[t]{17}{*}{9176 SRFCam. } & \multirow{17}{*}{$\begin{array}{l}\text { Liver disease and mouth } \\
\text { sores in children }\end{array}$} & \multirow[t]{17}{*}{ (Berhaut, 1971) } & \multirow[t]{17}{*}{ Fruit } & Methanol & SJfrMeOH & 12.84 \\
\hline & & & & & & Methanol & SJfr 1.1 & 1.43 \\
\hline & & & & & & Methanol & SJfr 2.1 & 0.09 \\
\hline & & & & & & Methanol & SJfr 2.2 & 0.46 \\
\hline & & & & & & Methanol & SJfr 2.3 & 1.07 \\
\hline & & & & & & Methanol & SJfr 3.1 & 1.00 \\
\hline & & & & & & Methanol & SJfr 3.2 & 1.57 \\
\hline & & & & & & Methanol & SJfr 3.3 & 0.95 \\
\hline & & & & & & Methanol & SJfr 3.41 & 0.85 \\
\hline & & & & & & Methanol & SJfr 3.42 & 1.09 \\
\hline & & & & & & Methanol & SJfr 3.5 & 0.12 \\
\hline & & & & & & Methanol & SJfr 3.6 & 0.072 \\
\hline & & & & & & Methanol & SJfr 4.1 & 0.79 \\
\hline & & & & & & Methanol & SJfr 4.2 & 0.23 \\
\hline & & & & & & Methanol & SJfr 4.3 & 0.19 \\
\hline & & & & & & Methanol & SJfr 4.4 & 0.05 \\
\hline & & & & & & Methanol & SJfr 4.5 & 0.0019 \\
\hline Asteraceae & $\begin{array}{l}\text { Spilanthes } \\
\text { filicaulis } \\
\text { (Schumach. and } \\
\text { Thonn.) } \\
\text { C.D.Adams }\end{array}$ & 11136/SFRCam & $\begin{array}{l}\text { Cough or cough with } \\
\text { haemoptysis }\end{array}$ & $\begin{array}{l}\text { (Adjanohoun et } \\
\text { al., 1996) }\end{array}$ & $\begin{array}{l}\text { Whole } \\
\text { plant }\end{array}$ & Methanol & SF & 8.65 \\
\hline \multirow[t]{3}{*}{ Annonaceae } & \multirow{3}{*}{$\begin{array}{l}\text { Uvaria baumannii } \\
\text { Engl. and Diels }\end{array}$} & \multirow[t]{3}{*}{ 6427/SRF/Cam } & \multirow[t]{3}{*}{ Fatigue, abscess } & \multirow[t]{3}{*}{ Local claims } & Twig & Ethanol & UBtwMeOH & 1.30 \\
\hline & & & & & Leaf & Ethanol & UBlMeOH & 0.71 \\
\hline & & & & & Twig & Ethanol & UBtwI & 1.60 \\
\hline Annonaceae & Uvariodendron & 28734/SFR/CAM & Malaria & Local claims & Twig & Ethanol & UCtwI & 0.50 \\
\hline
\end{tabular}


V. F. DONKENG DONFACK et al. / Int. J. Biol. Chem. Sci. 8(1): 273-288, 2014

\begin{tabular}{|c|c|c|c|c|c|c|c|c|}
\hline & $\begin{array}{l}\text { callophylium R.E } \\
\text { Fries }\end{array}$ & & & & Twig & Ethanol & UCtwMeOH & 0.42 \\
\hline Annonaceae & $\begin{array}{l}\text { Uvaria zenkeri } \\
\text { Engl. and Diels }\end{array}$ & $57355 \mathrm{HNC}$ & Gun-stock & (Bele et al., 2011) & Twig & Ethanol & UZtwMeOH & 0.59 \\
\hline \multirow[t]{2}{*}{ Annonaceae } & \multirow{2}{*}{$\begin{array}{l}\text { Uvariodendron } \\
\text { molendense (Engl. } \\
\text { and Diels) R.E. } \\
\text { Fries }\end{array}$} & \multirow[t]{2}{*}{$41685 \mathrm{HNC}$} & \multirow[t]{2}{*}{ Malaria } & \multirow[t]{2}{*}{ Local claims } & Twig & Ethanol & UMtwMeOH & 0.20 \\
\hline & & & & & Leaf & Ethanol & UMlMeOH & 1.44 \\
\hline \multirow[t]{5}{*}{ Annonaceae } & \multirow{5}{*}{$\begin{array}{l}\text { Xylopia aethiopica } \\
\text { (Dunal) A Rich }\end{array}$} & \multirow[t]{5}{*}{ 28725/SFR/Cam } & \multirow{5}{*}{$\begin{array}{l}\text { Buruli ulcer, Cough, } \\
\text { carminative, and as a post- } \\
\text { partum tonic. } \\
\text { Stomach ache, treatment of } \\
\text { bronchitis, biliousness and } \\
\text { dysentery }\end{array}$} & \multirow{5}{*}{$\begin{array}{l}\text { (Iwu, 1993; } \\
\text { Yemoa et al., } \\
\text { 2011) }\end{array}$} & Fruit & Ethanol & XAEfrMeOH & 1.98 \\
\hline & & & & & Leaf & Ethanol & XAElMeOH & 4.27 \\
\hline & & & & & Fruit & Ethanol & $\mathrm{XAEfrH}_{2} \mathrm{O}$ & 0.18 \\
\hline & & & & & Stem & Ethanol & XAEstMeOH & 0.10 \\
\hline & & & & & Leaf & Ethanol & XAEII & 0.30 \\
\hline \multirow[t]{11}{*}{ Annonaceae } & \multirow[t]{11}{*}{$\begin{array}{l}\text { Xylopia parviflora } \\
\text { A Rich }\end{array}$} & \multirow[t]{11}{*}{ 38322/HNC } & \multirow{11}{*}{$\begin{array}{l}\text { Bronchitis, dysentery and } \\
\text { febrile pains, Asthma, } \\
\text { stomach aches and } \\
\text { rheumatism }\end{array}$} & \multirow[t]{11}{*}{ (Bele et al., 2011) } & $\begin{array}{l}\text { Stem } \\
\text { bark }\end{array}$ & Ethanol & $\mathrm{XAsbH}_{2} \mathrm{O}$ & 0.94 \\
\hline & & & & & Twig & Ethanol & XAtwI & 0.75 \\
\hline & & & & & Root & Ethanol & XArI & 1.45 \\
\hline & & & & & Leaf & Ethanol & XAlMeOH & 1.83 \\
\hline & & & & & $\begin{array}{l}\text { Stem } \\
\text { bark }\end{array}$ & Ethanol & XAsbI & 2.02 \\
\hline & & & & & Root & Ethanol & $\mathrm{XArH}_{2} \mathrm{O}$ & 0.31 \\
\hline & & & & & Root & Ethanol & XArHex & 0.09 \\
\hline & & & & & Root & Ethanol & $\mathrm{XArMeOH}$ & 0.49 \\
\hline & & & & & Leaf & Ethanol & XAlI & 3.99 \\
\hline & & & & & Twig & Ethanol & XAtwMeOH & 1.83 \\
\hline & & & & & $\begin{array}{l}\text { Stem } \\
\text { bark }\end{array}$ & Ethanol & $\mathrm{XAsbMeOH}$ & 1.57 \\
\hline \multirow[t]{3}{*}{ Annonaceae } & \multirow{3}{*}{$\begin{array}{l}\text { Xylopia parviflora } \\
\text { A Rich }\end{array}$} & \multirow[t]{3}{*}{ 42351HNC } & \multirow{3}{*}{$\begin{array}{l}\text { Stomach disorders and } \\
\text { barrenness, } \quad \text { Headache, } \\
\text { analgesic and antispasmodic } \\
\text { purposes }\end{array}$} & \multirow{3}{*}{$\begin{array}{l}\text { (Nishiyama et al., } \\
\text { 2004) }\end{array}$} & Fruit & Ethanol & $\mathrm{XPfrMeOH}$ & 1.65 \\
\hline & & & & & Leaf & Ethanol & XPIMeOH & 1.96 \\
\hline & & & & & Stem & Ethanol & XPstMeOH & 2.74 \\
\hline
\end{tabular}

purposes 
V. F. DONKENG DONFACK et al. / Int. J. Biol. Chem. Sci. 8(1): 273-288, 2014

Table 2: MIC and MBC from the antimycobacterial screening of plant extracts.

\begin{tabular}{|c|c|c|c|c|c|c|c|c|c|c|}
\hline \multirow[t]{2}{*}{ Extracts code } & \multicolumn{5}{|c|}{ MIC $(\mu \mathrm{g} / \mathrm{ml})$} & \multicolumn{5}{|c|}{ MBC $(\mu \mathrm{g} / \mathrm{ml})$} \\
\hline & MS & MA & BCG & MU & MTB & MS & MA & BCG & MU & MTB \\
\hline \multicolumn{11}{|c|}{ Plants fractions and purified compounds at $250 \mu \mathrm{g} / \mathrm{ml}$} \\
\hline ACstI & 250 & NA & NA & 7.81 & NA & $>250$ & NA & NA & 7.81 & NA \\
\hline ACsbI & 250 & NA & 125 & 1.95 & NA & $\geq 250$ & NA & $>250$ & 62.50 & NA \\
\hline SJfr 3.2 & NA & NA & 15.62 & 62.50 & NA & NA & NA & 62.50 & $\geq 250$ & NA \\
\hline SJfr 3.3 & NA & NA & 31.25 & NA & 250 & NA & NA & 31.25 & NA & 250 \\
\hline SJfr 3.41 & NA & NA & NA & 62.50 & NA & $\mathrm{NA}$ & NA & NA & 250 & NA \\
\hline SJfr 3.42 & NA & NA & 31.25 & NA & NA & NA & NA & 31.25 & NA & NA \\
\hline SJfr 3.6 & NA & NA & 3.90 & NA & NA & NA & NA & 31.25 & NA & NA \\
\hline SJfr 4.2 & NA & NA & 125 & NA & 250 & NA & NA & 125 & NA & 250 \\
\hline SJfr 4.3 & NA & NA & 250 & NA & NA & NA & NA & 250 & NA & NA \\
\hline SJfr 4.4 & NA & $\geq 250$ & NA & NA & NA & NA & $>250$ & NA & NA & NA \\
\hline SJfr 4.5 & NA & NA & NA & 62.50 & NA & NA & NA & NA & 125 & NA \\
\hline \multicolumn{11}{|c|}{ Plants crude extracts at $12,500 \mu \mathrm{g} / \mathrm{ml}$} \\
\hline PSsbMeOH & 6,250 & $>12,500$ & 12,500 & 3,125 & 6,250 & 12,500 & $>12,500$ & 12,500 & 3,125 & 12,500 \\
\hline $\mathrm{XArH}_{2} \mathrm{O}$ & 12,500 & NA & 3,125 & NA & 6,250 & 12,500 & NA & 3,125 & NA & 12,500 \\
\hline POsbMeOH & 12,500 & NA & 6,250 & NA & NA & $\geq 12,500$ & NA & 12,500 & NA & NA \\
\hline $\mathrm{AMl}$ & NA & NA & 12,500 & NA & NA & NA & NA & 12,500 & NA & NA \\
\hline AMfr & NA & NA & 6,250 & NA & NA & NA & NA & 6,250 & NA & NA \\
\hline $\mathrm{SF}$ & NA & NA & 12,500 & NA & NA & NA & NA & 12,500 & NA & NA \\
\hline CMst & NA & NA & 12,500 & NA & NA & NA & NA & 12,500 & NA & NA \\
\hline $\mathrm{CMr}$ & NA & NA & 3,125 & NA & 12,500 & NA & NA & 6,250 & NA & 12,500 \\
\hline AMnsbMeOH & NA & NA & 6,250 & NA & 12,500 & NA & NA & 6,250 & NA & 12,500 \\
\hline $\mathrm{XAsbH}_{2} \mathrm{O}$ & NA & NA & 12,500 & NA & NA & NA & NA & 12,500 & NA & NA \\
\hline XAsbI & NA & NA & 12,500 & NA & NA & NA & NA & 12,500 & NA & NA \\
\hline UBtwMeOH & NA & NA & 1,562 & NA & NA & NA & NA & 3,125 & NA & NA \\
\hline AMntwMeOH & NA & $\mathrm{NA}$ & 3,125 & $\mathrm{NA}$ & 6,250 & NA & $\mathrm{NA}$ & 6,250 & NA & 6,250 \\
\hline \multicolumn{11}{|c|}{ Positive controls $(\mu \mathrm{g} / \mathrm{ml})$} \\
\hline SM & NT & $>18.00$ & NT & 0.12 & 0.50 & NT & NT & NT & 0.25 & 0.5 \\
\hline EMB & 0.46 & $>160$ & 1.50 & NT & NT & $>1.87$ & $>160$ & $>3.00$ & NT & NT \\
\hline
\end{tabular}


Table 3: Cytotoxicity of ACsbI, ACstI, and SJfr 3.6 against MRC5 cells.

\begin{tabular}{cc}
\hline Plant fraction & ${ }^{*} \mathbf{I C}_{\mathbf{5 0}} \pm \mathbf{S D}(\boldsymbol{\mu g} / \mathbf{m l})$ \\
\hline ACstI & $50.82 \pm 1.04$ \\
ACsbI & $>500$ \\
SJfr 3.6 & $139.4 \pm 1.03$ \\
\hline *Plant fractions were tested in triplicate; IC $_{50}=$ extract concentration that inhibits \\
$50 \%$ of cell growth.
\end{tabular}

\section{DISCUSSION}

Amongst the 19 plants collected in this study, 9 were reported to be used to treat respiratory tract infections, including cough, bronchitis, asthma, pneumonia, TB, cough with haemoptysis and other bronchopulmonary disorders. In addition, 3 plants were reported as used to treat ulcers (ex. BU) and 7 to control other general symptoms like fevers, headache, and pain (Nishiyama et al., 2004; Ibekwe and Orok, 2010).

From the results presented (Table 2), extracts were more active on slow growing strains such as M. tuberculosis, M. ulcerans, and BCG than on faster growing strains such as M. smegmatis and M. avium.

Overall, apart from M. avium, all the mycobacterial strains showed susceptibility to at least 1 extract. $M$. avium is basically resistant to many drugs used to treat other mycobacterial infections. Of note, this bacterial species showed low susceptibility to the positive controls (SM, MIC> $18 \mu \mathrm{g} / \mathrm{ml}$; EMB, MIC $>160 \mu \mathrm{g} / \mathrm{ml}$ ). This resistance is usually ascribed to the impermeability of its lipid-rich cell wall, but it may also occur through emergence of highly resistant strains, patient intolerance to treatment, or erratic compliance (Portillo-Gomez et al., 1995; Ramirez et al., 2007). Furthermore most $M$. avium isolates segregate into smoothtransparent-, smooth-opaque- and roughcolony-type variants on agar plates. $M$. avium strain 2447 is a smooth transparent (SmT) colony isolated from AIDS patients (Cangelosi et al., 2001) and for unknown reasons, transparent variants tend to be more drug-resistant than opaque variants (Florido et al.,1999). The low susceptibility of M. avium strain 2447 might also be due to the bacterial load used in this study.

Two fractions from A. chlorantha stem and stemback (ACstI and ACsbI) showed activity against $M$. smegmatis at MIC value of $250 \mu \mathrm{g} / \mathrm{ml}$ for both and against $M$. ulcerans at MIC values of 1.95 and 7.81 $\mu \mathrm{g} / \mathrm{ml}$ respectively. ACstI and ACsbI showed bactericidal activity on M. ulcerans with MBC values of 7.81 and $62.50 \mu \mathrm{g} / \mathrm{ml}$ respectively. In a similar approach, previous studies were conducted on M. ulcerans. The MIC value obtained by Coulibaly et al. (2011) with an aqueous extract from Phyllanthus amarus was $32 \mathrm{mg} / \mathrm{ml}$, while results obtained by Yemoa et al. (2011) from the screening of 49 methanolic extracts from different plants showed MIC values ranging from $125-250 \mu \mathrm{g} / \mathrm{ml}$.

Overall, investigation of plants products is so far scarce for the management and control of BU depite the urgent need for effective drugs. M. ulcerans has shown high susceptibility to A. chlorantha stem and stem bark extracts (ACsbI and ACstI), $S$. juglandifolia compound (SJfr 4.5). A. chlorantha also known as the African yellow wood, is a dense forest tree found in Cameroon, Nigeria and Gabon where Buruli ulcer is endemic (WHO, 2011). In the southern forest zone of Cameroon, it is used traditionally to treat tuberculosis and some forms of ulcer (Adjanohoun et al., 1996; Kimbi et al., 1996). This plant should be further investigated for the treatment of BU.

BCG appeared to be the most sensitive strain to much of extracts and fractions. Extracts from S. juglandifolia were found to be the most active on this strain. These results suggest that, the fruits of $S$. 
juglandifolia should be further investigated for the treatment of bovine tuberculosis.

Results from the cytotoxicity studies suggest a critical management of doses of traditional potions that are given to patients attending traditional herbal practitioners. Extract from A. chlorantha (ACsbI) was found to be safe at 2 fold the MIC value (activity against $M$. smegmatis). A previous work assessed the cytotoxicity of the water extract of A. chlorantha and showed to be safe on Vero cells up to $0.025 \mathrm{mg} / \mathrm{ml}$ (Fasola et al., 2011), corroborating our findings. This result suggests that the activity of this fraction might be directed towards microorganisms rather than eukaryotic cells. The result obtained with ACsbI against the intracellular bacteria supports the local use of $A$. chlorantha stem bark in the treatment of a wide range of infections (Adjanohoun et al., 1996; Kimbi et al., 1996; Boyom et al., 2009; Bele et al., 2011; Tsabang et al., 2012). Moreover, ACsbI fraction, which is obtained from an Annonaceae plant, might contain acetogenins derivatives. This group of compounds was reported to be the most powerful of the known inhibitors of complex I (NADH: ubiquinone oxidoreductase) in mammalian and insect mitochondrial electron transport systems (Lewis et al., 1993). In addition, they were shown to be potent inhibitors of NADH oxidase of plasma membranes (Morré et al., 1995); leading to ATP deprivation and apoptosis (programmed cell death). Moreover, they are potently cytotoxic with bactericidal activities (Rupprecht et al., 1990; Guadaño et al., 2000; Rakotomanga et al., 2004; Kamkumo et al., 2012) that could explain the exerted antimycobacterial activity.

\section{Conclusion}

The study designed to assess the antimycobacterial activity of extracts from 19 Cameroonian medicinal plants highlighted the potency of natural products against 4 species of mycobacteria, M. smegmatis, BCG, $M$. tuberculosis, and M. ulcerans. Moreover, ACsbI significantly inhibited the growth of intracellular $M$. smegmatis and was also shown not to be cytotoxic for MRC5 cell line and BMDM. Considering the anti-TB drug resistance and the increasing burden of the emerging $\mathrm{BU}$, the results achieved are promising, and indicate that new drug candidates could be discovered through this approach. Of note, very few reports are available on investigation of plant products against $M$. ulcerans. We anticipate that further detailed studies within this focus will enable us to uncover the hidden potency of particular natural products from the Cameroonian biodiversity against TB and BU.

\section{ACKNOWLEDGEMENTS}

The authors are grateful to acknowledge the financial support of Robert S. McNamara Fellowships Program (RSM). We are also thankful to the staff of the Cameroon National Herbarium for assistance in plant identification and specimen archiving.

\section{REFERENCES}

Adeleye IA, Onubogu CC, Ayolabi CI, Isawumi AO, Nshiogu ME. 2008. Screening of crude extracts of twelve medicinal plants and "Wondercure" concoction used in Nigeria unorthodox medicine for activity against Mycobacterium tuberculosis isolated from Tuberculosis patients sputum. Afr. J. Inf. Dis., 2: 85-93.

Adewole SO, Ojewole JAO. 2009. Protective effects of Annona muricata Linn.(Annonaceae) leaf aqueous extract on serum lipid profiles and oxidative stress in hepatocytes of streptozotocintreated diabetic rats. Afr. J. Tradit. Complem. Alt. Med., 6: 30-41.

Adjanohoun EJ, Aboubakar N, Dramane K, Ebot ME, Ekpere JA, Enow-Orock EG, Focho D, Gbilé ZO, Kamanyi A, Kamsu KJ, Keita A, Mbenkum T, Mbi CN, Mbiele AL, Mbome IL, Mubiru NK, Nancy WL, Nkongmeneck B, Satabie B, Sofowora A, Tamze V, Wirmum CK. 1996. Contribution to Ethnobotanical and floristic studies in Cameroon. Organization of African Unity; Scientific 
Technical and Research Commission: Yaoundé.

Alali FQ, Liu XX, McLaughlin JL. 1999. Annonaceous acetogenins: recent progress. J. Nat. Prod., 62: 504-540.

Anon. 2002. Traditional Medicine Strategy 2002-2005. World Health Organization. Geneva.

Asiedu K, Scherpbier R, Raviglione M. 2000. Buruli Ulcer, Mycobacterium Ulcerans Infection, World Health Organization Global buruli Ulcer Initiative: Geneva.

Bele MY, Focho DA, Egbe EA, Chuyong BG. 2011. Ethnobotanical survey of the uses of Annonaceae around mount Cameroon. Afr. J. Plant Sci., 5: 237-247.

Berhaut J. 1971. Flore Illustrée du Sénégal. (Tome I): Acanthacées à Avicenniacées. Ministère du Développement Rural et de l'Hydraulique, Direction des Eaux et Forêts, Dakar, Sénégal.

Boyom FF, Kemgne EM, Tepongning R, Ngouana V, Mbacham WF, Tsamo E, Amvam ZPH, Gut J, Rosenthal PJ. 2009. Antiplasmodial activity of extracts from seven medicinal plants used in malaria treatment in Cameroon. $J$. Ethnopharmacol., 123: 483-488.

Cangelosi G, Palermo CO, Bermudez LE. 2001. Phenotypic consequences of red white colony type variation in Mycobacterium avium. Microbiology, 147: 527-533.

Chan PF, Roslida AH. 2012. Evaluation of anti-inflammatory activities of ethanolic extract of Annona muricata leaves. Braz. J. Pharmacognosy, 22: 1301-1307.

Coulibaly B, N'guessan KR, Aka N, Ekaza E, N'golo D, Coulibaly TN, Ouattara L, Bahi C, Coulibaly A, Assandé JM, Mohui P, Yao H, Djaman AJ, Dosso M. 2011. Activité anti-mycobactérienne in vitro des extraits de Phyllanthus amarus (Schum et Thonn) sur les souches de Mycobacterium ulcerans en Côte d'Ivoire. Bull. Soc. Royale Sci. Liège, 80: 759-771.
Daley CL, Griffith DE. 2010. Pulmonary nontuberculous mycobacterial infections. Int. J. Tuberc. Lung Dis., 14(6): 665-671.

Fasola TR, Adeyemo FA, Adeniji JA, Okonko IO. 2011. Antiviral potentials of Enantia chlorantha extracts on Yellow Fever Virus. Nat. \& Sci. 9(9): 99-105.

Florido M, Goncalves AS, Silva RA, Ehlers S, Cooper AM, Rui A. 1999. Resistance of virulent Mycobacterium avium to gamma interferon-mediated antimicrobial activity suggests additional signals for induction of mycobacteriostasis. Am. Soc. Microb. Inf. Immunity, 67: 3610-3618.

Focho DA, Egbe EA, Chuyong GB, Fongod AGN, Fonge BA, Ndam WT, Youssoufa BM. 2010. An ethnobotanical investigation of the Annonaceae on Mount Cameroon. J. Med. Plant. Res., 4: 2148-2158.

Guadaño A, Gutiérrez C, DelaPeña E, Cortes D, González CA. 2000. Insecticidal and mutagenic evaluation of two annonaceous acetogenins. J. Nat. Prod., 63: 773-776.

Hannan A, Ikram UM, Usman M, Hussain S, Absar M, Javed K. 2011. Antimycobacterial activity of garlic (Allium sativum) against multi-drug resistant and non-multi-drug resistant Mycobacterium tuberculosis. Pak. J. Pharm. Sci., 24: 8185.

Ibekwe HA, Orok EE. 2010. Proximate Composition of Aframomum melegueta seeds, Garcinia kola seeds and growth performance of Broiler Chicks treated with powders from these seeds. Int. J. Poultry Sci., 9: 1152-1155.

Igoli JO, Gray AI, Clements CJ, Mouad HA. 2011. Anti-Trypanosomal activity and cytotoxicity of some compounds and extracts from Nigerian medicinal plants. Phytochem. Bioactivities Impact Health, 16: 375-388.

Iwu MM. 1993. Handbook of African Medicinal Plants. CRC Press: Florida.

Kadiri AB. 2009. An examination of the usage of herbal contraceptives and abortifacients in Lagos State, Nigeria. Ethnobotanical Leaflets, 13: 140-146. 
Kamkumo RG, Ngoutane AM, Tchokouaha LRY, Tsouh, FPV, Madiesse EAK, Legac J, Kezetas JJB, Lenta BN, Boyom FF, Dimo T, Mbacham WF, Gut J., Rosenthal PJ. 2012. Compounds from Sorindeia juglandifolia (Anacardiaceae) exhibit potent anti-plasmodial activities in vitro and in vivo. Malaria J., 11: 382.

Kimbi HK, Fagbenro-Beyioku AF. 1996. Efficacy of Cymbopogon giganteus and Enantia chlorantha against chloroquine resistant Plasmodium yoelii nigeriensis. East African Med. J., 73: 636-637.

Kreuchunas A, Mosher RE. 1956. The Preparation of 2,3,6-Trihydroxybenzoic Acid and Its Methyl Ester. J. Org. Chem., 21(5): 589-590.

Lewis MA, Arnason JT, Philogene BJR, Rupprecht JK, McLaughlin JL. 1993. Inhibition of respiration at site $\mathrm{I}$ by asimicin, an insecticidal acetogenin of the Pawpaw, Asimina triloba (Annonaceae). Pesticide Biochem. Physiol., 45: 15-23.

Mat Salleh K, Ahmad F. 1989. The distribution of alkaloids, flavonoids and other active constituents in Malaysian Annonaceae. In Systematic Identification of Natural Products. Said IM, Din L (eds). UNESCO: Kuala Lumpur.

Morré DJ, De Cabo R, Farley C, Oberlies NH, McLaughlin JL. 1995. Mode of action of bullatacin, a potent antitumor acetogenin: inhibition of NADH oxidase activity HeLa and HL-60 but not liver, plasma membranes. Life Sci., 56: 343-348.

NCCLS (National Committee for Clinical Laboratory Standards). 1999. Methods for Determining Bactericidal Activity of Antimicrobial Agents. Approved guideline. NCCLS; 18.

Nishiyama $\mathrm{Y}$, Moriyasu $\mathrm{M}$, Ichimaru $\mathrm{M}$, Iwasa K, Kato A, Mathenge SG, Mutiso, PBC, Juma FD. 2004. Quaternary isoquinoline alkaloids from Xylopia parviflora. Phytochemistry, 65: 939-944.

Noumi E, Eboule AF, Nanfa R. 2011. Traditional health care of male infertility in Bansoa, West Cameroon. Int. J. Biomed. Pharm. Sci., 2: 42-50.
Nwaka S, Hudson A. 2006. Innovative lead discovery strategies for tropical diseases. Nat. Rev. Drug Discov., 5: 940-955.

Okunade AL, Elvin-Lewis PF, Lewis WH. 2004. Natural antimycobacterial metabolites: current status. Phytochemistry, 65: 1017-1072.

Oliveira MS, Fraga AG, Torrado E, Castro AG, Pereira JP, Filho AL, Milanezi F, Schmitt FC, Meyers WM, Portals F, Silva MT, Pedrosa J. 2005. Infection with Mycobacterium induces persistent inflammatory responses in mice. Infect. Immun., 73: 6299-6310.

Portillo-Gomez L, Nair J, Rouse DA, Morris SL. 1995. The absence of genetic markers for streptomycin and rifampicin resistance in Mycobacterium avium complex strains. J. Antimicrob. Chemother., 36: 1049-1053.

Promega. 2011. New Assays for epigenetics and drug screening; Cell-Based and Biochemical Assays. Promega GMBH High-Tech-Park (www.promega.com).

Rakotomanga M, Razakantoanina V, Raynaud S, Loiseau PM, Hocquemiller R, Jaureguiberry G. 2004. Antiplasmodial activity of acetogenins and inhibitory effect on Plasmodium falciparum adenylatetranslocase. J. Chem., 16: 350356.

Ramirez J, Mason C, Ali J. 2007. Use of Mefloquine in Multidrug-Resistant Mycobacterium avium Complex Pulmonary Disease in an HIV-Negative Patient. Curr. Ther., 68: 421-429.

Rastogi N, Potar MC, David HL. 1987. Intracellular growth of pathogenic mycobacteria in the continuous murine macrophage cell line J-774: Ultrastructure and drug-susceptibility studies. Curr. Microbiol., 16: 79-92.

Rupprecht JK, Chang JM, McLaughin JL. 1990. Annonaceous acetogenins: a review. J. Nat. Prod., 53: 237-278.

Sharbati-Tehrani S, Stephan J, Holland G, Appel B, Niederweis M, Lewin A. 2005. Porins limit the intracellular persistence 
of Mycobacterium smegmatis. Microbiology, 151: 2403-2410.

Singh S, Kumar P, Sharma S, Mumbowa F, Martin A, Durier N. 2012. Rapid Identification and Drug Susceptibility Testing of Mycobacterium tuberculosis: Standard Operating Procedure for Non Commercial Assays: Part 3: Colorimetric Redox Indicator Assay. J. Lab. Physicians, 4: 120-126.

Sexton P, Harrison AC. 2008. Susceptibility to nontuberculous mycobacterial lung disease. Eur. Respir. J., 31(6): 13221333.

Tane P, Tatsimo SD, Ajimele GA, Connolly JD. 2006. Bioactive Metabolites. In 11 NAPRECA Symposium Book of Proceedings, Antananarivo Madagascar.

TB Alliance. 2011. Annual Report on Global alliance for TB Drugs Development (www.tballiance.org).

Tsabang N, Tsouh FPV, Yamthe TLR, Noguem B, Bakarnga-Via I, Dongmo NMS, Nkongmeneck BA, Boyom FF. 2012. Ethnopharmacological survey of Annonaceae medicinal plants used to treat malaria in four areas of Cameroon. J. Ethnopharmacol., 139: 171-180.

Vairappan CS, Tan KL. 2009. C-15 Halogenated Acetogenin with Antibacterial Activity against Food Pathogens. Malays. J. Sci., 28 (3): 263268.

Vikrant AA. 2011. Review on AntiTubercular Plants. Int. J. Pharm. Tech. Res., 3: 872-880.

WHO. 2004. Pathogenic Mycobacteria in Water: A Guide to Public Health Consequences, Monitoring and Management. WHO: Geneva.

WHO. 2011. Treatment of Mycobacterium ulcerans Disease (Buruli Ulcer), Guidance for Health Workers. WHO: Geneva.

Yemoa A, Gbenou J, Affolabi D, Moudachirou M, Bigot A, Anagonou S, Portaels F, Leclercq JQ, Martin A. 2011. Buruli ulcer: a review of in vitro tests to screen natural products for activity against Mycobacterium ulcerans. Planta Med., 77: 641-646. 